\title{
Frequency of concentrate supplementation for grazing beef cattle
}

\section{Frequência de suplementação concentrada para bovinos de corte em pastejo}

\author{
Ricardo Bonadimann ${ }^{1}$; Eduardo Henrique Bevitori Kling de Moraes $^{2 *}$; Kamila \\ Andreatta Kling de Moraes²; Douglas dos Santos Pina ${ }^{3}$; André Soares de Oliveira \\ Daniel Mendonça de Meneses ${ }^{5}$; Helio Stinguel ${ }^{5}$; Chafic Mustafé de Almeida ${ }^{5}$
}

\begin{abstract}
The objective of this study was to evaluate the effects of frequency of concentrate supplementation on the daytime feeding behavior (grazing, rumination, drinking, and idle times), production performance, and economic viability of grazing cattle in the rainy season. A total of 120 uncastrated Nellore animals with an average body weight (BW) of $382.5 \pm 32.2 \mathrm{~kg}$ were allocated to palisadegrass (Brachiaria brizantha) paddocks for the experiment. We evaluated supplements provided in the amount of $2.0 \mathrm{~kg} /$ animal, supplied three times weekly (3tw) or daily (7X). Animals supplemented 3X (5.46\%) spent more time (\%) drinking water than those supplemented $7 \mathrm{X}(3.72 \%)$. Grazing time and animal performance were not influenced by the frequency of supplementation. Average daily gain was 1.00 and $1.02 \mathrm{~kg} /$ animal for the groups under $3 \mathrm{X}$ and $7 \mathrm{X}$, respectively. Expenditures on transportation and labor are lower $(43 \%)$ when animals are supplemented 3X. Supplementation provided three times per week does not affect the grazing time or the performance of beef cattle in the rainy season, but rather implies an expressive reduction of expenditures on labor and distribution of supplements.
\end{abstract}

Key words: Performance. Grazing time. Economic viability.

\section{Resumo}

Objetivou-se avaliar os efeitos da frequência de suplementação concentrada sobre o comportamento ingestivo diurno (tempos de pastejo, de ruminação, de bebedouro e de ócio), o desempenho produtivo e a viabilidade econômica de bovinos de corte em pastejo no período das águas. Foram utilizados 120 animais da raça Nelore não-castrados com peso corporal (PC) médio de 382,5 $\pm 32,2 \mathrm{~kg}$ alocados em piquetes formados com capim Marandu (Brachiaria brizantha). Avaliaram-se suplementos ofertados em quantidade de 2,0 kg/animal distribuídos três vezes por semana (3X) e diariamente (7X). O tempo gasto (\%) no consumo de água foi maior para os animais que receberam suplementação $3 \mathrm{X}(5,46 \%)$ do que os animais que receberam suplementação $7 \mathrm{X}(3,72 \%)$. O tempo gasto com pastejo e desempenho dos animais não sofreram influência da frequência de oferta do suplemento. O ganho médio diário foi 1,00 e 1,02 kg/animal, respectivamente, para a suplementação 3X e 7X. Os gastos com transporte e mãode-obra são menores (43\%) quando suplementos são ofertados 3X. O fornecimento de suplementos três vezes por semana não afeta o tempo de pastejo e o desempenho de bovinos de corte no período das águas e implica em expressiva redução nos custos com a mão-de-obra e com a distribuição de suplementos. Palavras-chave: Desempenho. Tempo de pastejo. Viabilidade econômica.

\footnotetext{
${ }^{1}$ Discente de Zootecnia, Universidade Federal de Mato Grosso, UFMT, Campus de Sinop, MT, Brasil. E-mail: ricardo_ bonadimann@hotmail.com

${ }^{2}$ Profs., Núcleo de Estudos em Pecuária Intensiva, NEPI, UFMT Campus de Sinop, MT, Brasil. E-mail: edukling@ufmt.br; kamila@ufmt.br

${ }^{3}$ Prof., Escola de Medicina Veterinária e Zootecnia, Universidade Federal da Bahia, UFBA, Bahia, BA, Brasil. E-mail: douglaspinaufba@gmail.com

4 Prof., Núcleo de Pesquisa em Pecuária de Leite, NPLEITE, UFMT Campus de Sinop, MT, Brasil. E-mail: andresoli@ufmt.br

5 Discentes, Programa de Pós-Graduação em Zootecnia, UFMT, Campus de Sinop, MT, Brasil. E-mail: danielmeneseszoo@, hotmail.com; heliostinguel@gmail.com; chaficmustafe@hotmail.com

* Author for correspondence
} 


\section{Introduction}

The viability of beef cattle farming depends directly upon the economy of scale, which has operated with reduced profit margins. As a result, in beef cattle husbandry on pasture, the reduction of production expenses should depend not only on lower prices of concentrate supplements, but also simpler structures in terms of transport and distribution of these supplements and the consequent optimization of labor.

In this scenario, infrequent-supplementation strategies may be an alternative that makes it possible to decrease expenditures on the labor and equipment used in the supplementation of beef cattle reared on pasture (MORAES et al., 2010). However, if the frequency of supply of concentrate supplements is reduced to three times weekly, animals may display lower weight gains (ARTIOLI et al., 2015; COOKE et al., 2008; LOY et al., 2008). According to Cooke et al. (2008), decreasing the frequency of energy supplementation to three times per week reduced the performance of beef heifers reared on pasture during the rainy season by $18 \%$.

By contrast, some studies (MORAIS et al., 2014; PAULA et al., 2010; SIMIONI et al., 2009) have shown that cattle supplemented at intervals longer than one day (e.g., alternate days or three times per week) are able to maintain their performance levels, compared with animals receiving daily supplementation. Supplementation provided at intervals longer than one day have shown to be efficient; as stated by Moraes et al. (2010), this is explained by the fact that ruminants maintain low variations in their rumen ammonia levels $\left(\mathrm{NH}_{3}\right)$, which supposedly ensures adequate fermentation between the supplementation events.

Bohnert et al. (2002) reported that concentrate supplementation provided at a low frequency supports the nitrogen recycling activity in animals, because ruminants have the ability to maintain their rumen nitrogen levels even when supplementation is provided at a six-day interval. Buffering mechanisms existing in the animal metabolism possibly contribute to this, conjointly with anabolic stimuli.

In addition to the benefit of weight gain, knowing the feeding-behavior patterns of cattle supplemented at a lower weekly frequency is of paramount importance when defining practices for the management of supplementation distribution. Changes in the grazing behavior of animals receiving supplements at a lower frequency were observed by Pulido et al. (2009) and Loy et al. (2008). Based on these studies, infrequent supplementation may alter the feeding behavior of animals, which may lead to a lower intake of pasture DM.

Schauer et al. (2005), however, did not find alterations in the grazing time of beef cows receiving supplements on alternate days. Therefore, in view of these conflicting results, further studies are necessary to elucidate the interactions between the frequency of supplementation and the feeding behavior of grazing animals, especially in tropical conditions.

Just as important as evaluating the production efficiency of supplementation is the economic impact of this practice in the production system. In this way, once the production-related aspects of supplementation are assessed, it is also necessary to analyze its economic viability. Thus, decreasing the supplementation frequency can be a measure adopted in an attempt to reduce the costs of the work (CANESIN et al., 2014) involved in the supplement-distribution process.

The hypothesis investigated here is that reducing the frequency of supplementation to three times per week should not modify the feeding behavior and production performance of grazing beef cattle and, consequently, expenditures on the distribution of supplements can be reduced. We thus evaluated the effects of the frequency of concentrate supplementation on the daytime feeding behavior, production performance, and economic performance of beef cattle in the finishing stage, during the rainy season. 


\section{Materials and Methods}

The experiment was conducted on Talismã Farm, located in Santa Carmen - MT, Brazil, during the rainy season, between January and March 2012. The climate in the city of Santa Carmen is an Am (monsoon) type, according to the KöppenGeiger classification; i.e., tropical and rainy, with a short period of rains in the driest month. The city is located on Planalto dos Parecis, where the relief is homogenous, with little slope, at approximately $435.0 \mathrm{~m}$ above the sea level. The experimental area is situated at the geographical coordinates $11^{\circ} 55^{\prime} 26.1^{\prime \prime} \mathrm{S}$ and $55^{\circ} 14^{\prime} 03.8^{\prime \prime} \mathrm{W}$.

The experimental area consisted of two 11.9-ha Marandu grass (Brachiaria brizantha cv. Marandu) paddocks equipped with drinkers and feeders. To determine the total dry matter per hectare, on the first day of each experimental period, pasture samples were harvested at $10 \mathrm{~cm}$ above the soil in ten areas within a metal square frame $(0.5 \times 0.5 \mathrm{~m})$ chosen at random per paddock. The average DM matter and pasture allowance during the experiment were $3.56 \mathrm{t} \mathrm{ha}^{-1}$ and $8.39 \mathrm{~kg} \mathrm{DM} / 100 \mathrm{BW}$, with an average stocking rate of $5.1 \mathrm{AU} \mathrm{ha}^{-1}$. The amount of pasture consumed was determined by manually simulating the grazing activity, following the technique described by Johnson (1978).

A total of 120 uncastrated Nellore animals with an average body weight (BW) of $382.5 \mathrm{~kg}$ were divided into two lots with 60 animals in each paddock. Before the experimental data were collected, animals underwent a period of 20 days of adaptation to supplements (Table 1), which were provided $(1000 \mathrm{~h})$ in quantities corresponding to $2.0 \mathrm{~kg} \mathrm{~kg} / \mathrm{animal}$, at different weekly frequencies (Table 2). Supplements were provided in uncovered plastic troughs $(59 \times 88 \mathrm{~cm}$ each $)$ with access from both sides.

The experimental structure was a completely randomized block design in which two weekly frequencies of supply of concentrate supplementation were evaluated. Animals were weighed every 30 days to estimate average daily gain, and their final BW was obtained at the end of 120 experimental days. To minimize the influence of possible variations in pasture dry matter (DM) availability, the animals remained in each paddock for seven days; thereafter, they were rotated across the paddocks (maintaining the application of the same treatments to the animals).

Samples of pasture and supplements (Table 3) were analyzed for the concentrations of DM, organic matter, crude protein, ether extract, and ash according to AOAC (1990). The neutral detergent fiber was determined by following the methods of Van Soest and Robertson (1994), with samples treated with heat-stable alpha-amylase, without using sodium sulfite (MERTENS, 2002).

Table 1. Supplement composition.

\begin{tabular}{lc}
\hline \multicolumn{1}{c}{ Ingredient } & $(\%)$ \\
\hline Protein mixture $(60 \% \text { crude protein })^{1}$ & 5.0 \\
Soybean meal & 15.0 \\
Ground corn & 80.0 \\
\hline
\end{tabular}

${ }^{1} \mathrm{Ca}(\min / \max ) 60 / 100 \mathrm{~g}, \mathrm{Co}(\min ) 15 \mathrm{mg}, \mathrm{Cu}(\min ) 130 \mathrm{mg}, \mathrm{S}(\min ) 6.500 \mathrm{mg}, \mathrm{EE}(\min ) 10 \mathrm{~g}, \mathrm{ADF}(\max ) 100 \mathrm{~g}, \mathrm{~F}(\mathrm{max}) 100 \mathrm{mg}$, $\mathrm{P}$ (min) $10 \mathrm{~g}$, I (min) 1,5 mg, Mg (min) $5.000 \mathrm{mg}$, sodic monensin $270 \mathrm{mg}$, non-protein nitrogen, protein equivalent (max) $392 \mathrm{~g}$, $\mathrm{Se}(\min ) 0.45 \mathrm{mg}, \mathrm{Na}(\min ) 26 \mathrm{~g}$, humidity (max) $100 \mathrm{~g}, \mathrm{Zn}(\min ) 400 \mathrm{mg}-$ in $1 \mathrm{~kg}$. 
Table 2. Weekly frequency of supplementation.

\begin{tabular}{lcc}
\hline & \multicolumn{2}{c}{ Supplementation frequency } \\
\cline { 2 - 3 } \multicolumn{1}{c}{ Day of the week } & Three times per week (3tw) & Daily $(7 \mathrm{tw})$ \\
\hline Sunday & --- & 2.00 \\
Monday & 4.67 & 2.00 \\
Tuesday & --- & 2.00 \\
Wednesday & 4.67 & 2.00 \\
Thursday & --- & 2.00 \\
Friday & 4.67 & 2.00 \\
Saturday & --- & 2.00 \\
\hline Week total $^{-1}(\mathrm{~kg})$ & 14.00 & 14.00 \\
\hline
\end{tabular}

Table 3. Chemical composition ( $\mathrm{g} \mathrm{kg}^{-1}$ dry matter) of supplement and pasture.

\begin{tabular}{|c|c|c|}
\hline Item & Supplement & Pasture \\
\hline Dry matter & 897.5 & 429.2 \\
\hline Organic matter & 861.6 & 927.7 \\
\hline Crude protein & 162.8 & 108.7 \\
\hline Ether extract & 32.4 & 13.4 \\
\hline Ash & 138.4 & 72.3 \\
\hline Neutral detergent fiber & 119.4 & 709.6 \\
\hline
\end{tabular}

For the assessment of animal behavior, we adopted the method of direct visual observation (HUGHES; REID, 1951) for two consecutive days, performed by two trained observers. The following behavioral variables were studied: grazing time (time expended by the animals on the selection and seizure of the pasture, including the time gaps used in the dislocation to select the feed); rumination time (corresponding to the processes of regurgitation, re-chewing, re-insalivation, and re-swallowing); idle time (when the animals were standing or lying still, not performing any other apparent activity); and drinking time (period in which the animal consumed water). The behavioral activities were considered mutually exclusionary. Observations were made using binoculars from an approximate distance of $150 \mathrm{~m}$. To record the time expended on the activities, the animals were identified (nontoxic paint) and watched at every $20 \mathrm{~min}$, following Mezzalira et al. (2011), for daytime periods of $12 \mathrm{~h}$ (0600 h to $1800 \mathrm{~h})$.
For the economic evaluation, we considered the prices of finished cattle $\left(\mathrm{R} \$ \mathrm{~kg}^{-1}\right)$, supplement $\left(\mathrm{R} \$ \mathrm{~kg}^{-1}\right)$, transport ( $\mathrm{R} \$ \mathrm{~km}$ travelled $\left.{ }^{-1}-30 \mathrm{~km}\right)$, and labor $\left(\mathrm{R} \$ \mathrm{~h}^{-1}\right)$. The total expenditure on supplementation was calculated as the sum of the supplement, transport, and labor costs. Balance with supplementation was determined as the animal production value minus the total expenditure on supplementation.

Mean values for average daily gain, total daily gain, and final body weight were subjected to an analysis of variance, by the $\mathrm{F}$ test, with initial body weight used as a co-variable. To evaluate the animal behavior, the means of the two days under evaluation were used, by the Wilcoxon test. Analyses were performed via the GLM procedure of SAS (2001) statistical software, adopting $\alpha=0.05$. 


\section{Results and Discussion}

There was an effect $(\mathrm{P}<0.05)$ only for the time expended on water consumption $(\mathrm{P}<0.05)$, whereby the animals receiving supplements at a lower frequency expended more time performing this activity (Table 4). Contrastingly, Miorin et al. (2016) did not observe a higher water intake in animals receiving concentrate supplements at a lower frequency. According to them, there might have been a mechanism of adjustment to the higher salt intake by the animals. Benatti et al. (2012) also observed that supplementation at a lower frequency resulted in a longer time expended on water consumption as compared with daily supplementation.

Table 4. Mean values for daily time (\%) expended on behavioral activities as a function of supplementation frequency.

\begin{tabular}{lccc}
\hline \multirow{2}{*}{ Variable (\%) } & \multicolumn{2}{c}{ Supplementation frequency } & \multirow{2}{*}{ P-value } \\
\cline { 2 - 3 } & Three times per week (3tw) & Daily $(7 \mathrm{tw})$ & 0.3429 \\
Grazing & 43.36 & 39.32 & 0.0286 \\
Drinking & 5.46 & 3.72 & 0.5143 \\
Feeding at trough & 4.80 & 5.03 & 0.3429 \\
Idle activity & 46.41 & 51.94 & \\
\hline
\end{tabular}

Probability associated with the Wilcoxon test.

The longer time expended drinking water may be a consequence of the higher amount of DM from supplement consumed per supplementation event. The animals subjected to the lowest supplementation frequency consumed $4.67 \mathrm{~kg}$ DM supplement per supplementation event (Table 2) and consequently more mineral salts, which leads to increased water intake (NRC, 2000). In fact, Ledgard et al. (2015) and Spek et al. (2012) found that animals consuming more sodium per supplementation event drank more water. According to Spek et al. (2012), for every gram of sodium ingested, an additional $0.146 \mathrm{~kg}$ of water was consumed.

As reported by Carter and Grovum (1990) and Kunkle et al. (2000), a higher intake of mineral salts elevates the molality of the rumen fluid and stimulates greater water consumption. Harvey et al. (1986) and Spek et al. (2012) found an increase in the passage rate of rumen fluids with addition of salt to the concentrate, but did not observe the same response for solid particles, even for the finer particles. These observations (greater water intake) can be interpreted as an attempt of the animals to maintain the salt concentration in their body fluid within the physiological limits.
Despite the longer time consuming water, no differences were observed $(\mathrm{P}>0.05)$ for grazing time. Benatti et al. (2012) and Canesin et al. (2014) also found the same time expended on the grazing activity (considering the average of two days of evaluation) when comparing supplementation provided daily vs. three times weekly.

This behavior may be a reflection of the similar grazing times among animals irrespective of the supplementation frequency evaluated. Canesin et al. (2014) found the same pasture DM intake and grazing time between cattle receiving supplementation at a lower frequency and/or daily. These results demonstrate the relationships between grazing time and pasture intake. In studies conducted in tropical conditions, authors also did not observe differences in the intake of pasture DM (MORAES et al., 2010, BENATTI et al., 2014; MORAIS et al, 2014).

The grazing time reflects a greater or lesser ability of the animals to consumer pasture DM. As stated by Morais et al. (2014), the maintenance of grazing activity on the day they received supplement and the increase on the day they were not supplemented may explain the similar forage intakes between animals 
supplemented at a lower frequency and daily. According to those authors, this fact may demonstrate the adaptation mechanism of animals to seek food under inconstant supplementation conditions.

Sichonany (2012), on the other hand, observed a lower grazing time and higher intake of pasture DM in animals receiving supplementation at a lower frequency. According to the author, the higher intake of supplement per supplementation event led to a lower intake of pasture DM because the animals had reached the sensation of satiety.

With respect to the time expended at the trough, as reported by Benatti et al. (2012) and Sichonany (2012), no differences were observed ( $P>0.05)$ between the supplementation frequencies. Signoretti et al. (2012), by contrast, found that animals remained longer at the trough when the frequency of supplementation was reduced.

The time expended on supplement consumption depends, among other factors, on the quantity provided. Therefore, when increasing amounts of concentrate are supplied, animals commonly remain at the trough for a longer period to consume the entire load of supplement. Based on the present results, reducing the frequency of supplementation does not change the time animals take to consume the supplement, even when a larger amount is offered at each supplementation event. Despite the larger quantity of supplement provided three times per week, it was consumed on the same day it was provided.

In general, the feeding behavior of animals on pasture is influenced by several factors. For this reason, further studies on the possible interactions between feeding behavior and supplementation frequency should be carried out so that these factors can be better understood.

In terms of performance, the lower frequency of supply did not compromise ( $\mathrm{P}>0.05$ ) average daily gain or final body weight. This finding corroborates the results obtained by Canesin et al. (2007), Benatti et al. (2012), and Moraes et al. (2010), who evaluated daily supplementation in comparison with supplementation offered three times weekly.

The maintenance of performance by the animals when they were supplemented at a lower weekly frequency may be related to their adaptability to the use of the nutrients ingested. Ruminants are able to use the supplemental nitrogen and maintain microbial efficiency and satisfactory performance levels even when supplementation is provided at intervals longer than one day (BOHNERT et al., 2002).

Therefore, a possible maintenance of an attenuated and prolonged peak of rumen $\mathrm{NH}_{3}$ at the supplementation intervals may benefit the digestion process and preservation of nitrogen. According to Moraes et al. (2010), in tropical conditions, when supplemented at a low frequency, beef cattle are efficient in maintaining their $\mathrm{NH}_{3}$ concentration in the rumen fluid at adequate levels for growth and microbial activity. Those authors observed that even on the days the animals did not receive supplementation, $\mathrm{NH}_{3}$ levels were above the 8.0 and $10.0 \mathrm{mg} / \mathrm{dL}$ of rumen fluid suggested by Detmann et al. (2014) and Leng (1990) as optimal values for appropriate fermentation in tropical conditions.

A lower frequency of supplementation increases the endogenous synthesis of urea to be recycled and return to the rumen environment to be used by the microorganisms, particularly on days without supplementation (ATKINSON et al., 2010). A lack of effects of lower supplementation frequency has been observed on the body retention of nitrogen compounds (MORAES et al., 2010; RUFINO, 2015), which can also explain the maintenance of the animal performance in relation to the cattle supplemented daily, as found in the current experiment.

As demonstrated in the present study, animals that receive supplements at a lower frequency perform similarly to those supplemented daily (Table 5), proving the technical viability of the former management strategy. Therefore, once the technical and strategic aspects of supplementation are defined, it is also necessary to evaluate the economic viability (PAULA, et al., 2010). 
Table 5. Average daily gain $\left(\mathrm{kg}\right.$ day $\left.^{-1}\right)$, total weight gain $(\mathrm{kg})$ and final body weight $(\mathrm{kg})$ as a function of supplementation frequency.

\begin{tabular}{|c|c|c|c|c|}
\hline \multirow{2}{*}{ Item $^{1}$} & \multicolumn{2}{|c|}{ Supplementation frequency } & \multirow{2}{*}{ P-value } & \multirow{2}{*}{$\begin{array}{l}\text { CV } \\
(\%)\end{array}$} \\
\hline & Three times per week (3tw) & Daily (7tw) & & \\
\hline Average daily gain & 1.00 & 1.02 & 0.2456 & 15.82 \\
\hline Total weight gain & 88.10 & 78.02 & 0.2456 & 15.82 \\
\hline Final body weight & 466.33 & 467.84 & 0.3415 & 18.69 \\
\hline
\end{tabular}

${ }^{1}$ Means adjusted by covariate.

According to Moraes et al. (2010), the provision of supplements at a lower weekly frequency can be a supplement-management alternative for grazing cattle supplementation systems that could allow the producer to reduce spending on labor and equipment for supplementation. Providing the supplements at a lower frequency generated a reduction in expenditures on the distribution of the supplement and labor (Table 6), given the fewer days used for the distribution of supplements per week. The supplement cost was similar for the two supplementation frequencies (Table 7), which was an expected result, given that the amount of supplement provided per week was the same for both frequencies (Table 2).

Thus, the lower spending on the supplementation process obtained with the lowest distribution frequency was a result of the lower expenditure on transport and labor, which allowed for a
$43 \%$ reduction of costs, as compared with daily supplementation (Table 7). Paula et al. (2010) and Benatti et al. (2012) also found that labor costs decreased considerably with the supply of supplements at a lower weekly frequency.

This observation corroborates Berchielli et al. (2006) and Zervoudakis et al. (2008), who stated that the costs of transport and daily distribution of supplements for grazing beef cattle are very high. In this way, reducing these costs provided a higher net revenue when animals were supplemented three times per week.

This observation corroborates Berchielli et al. (2006) and Zervoudakis et al. (2008), who stated that the costs of transport and daily distribution of supplements for grazing beef cattle are very high. In this way, reducing these costs provided a higher net revenue when animals were supplemented three times per week.

Table 6. Productivity indices as a function of supplementation frequency.

\begin{tabular}{|c|c|c|}
\hline \multirow{2}{*}{ Item } & \multicolumn{2}{|c|}{ Supplementation frequency } \\
\hline & Daily $(7 \mathrm{tw})$ & Three times per week (3tw) \\
\hline \multicolumn{3}{|l|}{ 1. Prices of product, inputs, and labor } \\
\hline Finished cattle $\left(\mathrm{R} \$ \mathrm{~kg}^{-1}\right)^{1}$ & 4.31 & 4.31 \\
\hline Supplement $\left(\mathrm{R} \$ \mathrm{~kg}^{-1}\right)$ & 0.40 & 0.40 \\
\hline Transport $\left(\mathrm{R} \$ \mathrm{~km}\right.$ travelled $\left.^{-1}\right)$ & 0.30 & 0.30 \\
\hline Labor $\left(\mathrm{R} \$ \mathrm{~h}^{-1}\right)$ & 10.00 & 10.00 \\
\hline \multicolumn{3}{|l|}{ 2. Production data } \\
\hline Daily weight gain $\left(\mathrm{g} \mathrm{head}^{-1}\right)^{2}$ & 1010.00 & 1010.00 \\
\hline Supplement consumption $\left(\mathrm{g} \mathrm{head}^{-1}\right)$ & 2000.00 & 2000.00 \\
\hline Supplementation period (days) & 84.00 & 84.00 \\
\hline Supplement distribution $\left(\mathrm{km}\right.$ animal-day $\left.{ }^{-1}\right)$ & 0.50 & 0.22 \\
\hline Labor (h animal-day ${ }^{-1}$ ) & 0.20 & 0.01 \\
\hline
\end{tabular}


continuation

3. Animal production value

Daily per animal ( $\mathrm{R} \$$ head-day $\left.{ }^{-1}\right)$

4.31

4.40

In the period per animal $\left(\mathrm{R} \$\right.$ head-period $\left.{ }^{-1}\right)$

365.66

365.66

Per weight gain $\left({\left.\mathrm{R} \$ \mathrm{~kg}^{-1}\right)}^{-1}\right.$

4.31

4.31

${ }^{1} \mathrm{R} \$ 129.30 @{ }^{-1}$ (Source: IMEA; ${ }^{2}$ Average weight gain of all treatments (Table 5).

Table 7. Economic indices a function of supplementation frequency.

\begin{tabular}{|c|c|c|}
\hline \multirow{2}{*}{ Item } & \multicolumn{2}{|c|}{ Supplementation frequency ${ }^{1}$} \\
\hline & Daily (7tw) & Three times per week (3tw) \\
\hline \multicolumn{3}{|l|}{ 4. Expenditure on supplement } \\
\hline Daily per animal (R\$ head-day $\left.{ }^{-1}\right)$ & 0.80 & 0.80 \\
\hline In the period per animal $\left(\mathrm{R} \$\right.$ head $\left.^{-1}\right)$ & 67.20 & 67.20 \\
\hline Per weight gain $\left(\mathrm{R} \$ \mathrm{~kg}^{-1}\right)$ & 0.79 & 0.79 \\
\hline \multicolumn{3}{|l|}{ 5. Expenditure on transport } \\
\hline Daily per animal $\left(\mathrm{R} \$\right.$ day $\left.^{-1}\right)$ & 0.15 & 0.06 \\
\hline In the period per animal $\left(\mathrm{R} \$\right.$ head $\left.^{-1}\right)$ & 12.60 & 5.42 \\
\hline Per weight gain $\left(\mathrm{R} \$ \mathrm{~kg}^{-1}\right)$ & 0.15 & 0.06 \\
\hline \multicolumn{3}{|l|}{ 6. Expenditure on labor } \\
\hline Daily per animal $\left(\mathrm{R} \$\right.$ head $\left.^{-1}\right)$ & 0.20 & 0.09 \\
\hline In the period per animal $\left(\mathrm{R} \$\right.$ day $\left.^{-1}\right)$ & 16.80 & 7.22 \\
\hline Per weight gain $\left(\mathrm{R} \$ \mathrm{~kg}^{-1}\right)$ & 0.20 & 0.09 \\
\hline \multicolumn{3}{|l|}{ 7. Expenditure on supplementation ${ }^{2}$} \\
\hline Daily per animal $\left(\mathrm{R} \$\right.$ day $\left.^{-1}\right)$ & 1.15 & 0.95 \\
\hline In the period per animal $\left(\mathrm{R} \$\right.$ head $\left.^{-1}\right)$ & 96.60 & 79.84 \\
\hline Per weight gain $\left(\mathrm{R} \$ \mathrm{~kg}^{-1}\right)$ & 1.14 & 0.97 \\
\hline \multicolumn{3}{|l|}{ 8. Balance with supplementation ${ }^{3}$} \\
\hline Daily per animal $\left(\mathrm{R} \$\right.$ day $\left.^{-1}\right)$ & 3.20 & 3.40 \\
\hline In the period per animal $\left(\mathrm{R} \$\right.$ head $\left.^{-1}\right)$ & 269.06 & 285.82 \\
\hline Per weight gain $\left(\mathrm{R} \$ \mathrm{~kg}^{-1}\right)$ & 3.17 & 3.37 \\
\hline \multicolumn{3}{|l|}{ 9. Relative balance with supplementation ${ }^{4}$} \\
\hline Per animal & 100 & 160 \\
\hline Per weight gain & 100 & 160 \\
\hline
\end{tabular}

${ }^{2}$ Expenditure on supplement + expenditure on transport + expenditure on labor; ${ }^{3}$ Animal production value (Table 6 ) - expenditure on supplementation; ${ }^{4} 7 \mathrm{X}=100$.

Benatti et al. (2012) and Paula et al. (2010) also found a better economic return with supplementation provided three times weekly, and, according to the authors, the lower costs involved in the supplement distributed three times per week allowed for better economic returns in comparison with daily supplementation. Decreasing the frequency of supplementation without reducing the animal performance improves the logistics of supplement distribution, improving economic results.

Therefore, it can be inferred that the provision of supplement three times per week does not affect the grazing time or performance of grazing cattle in the rainy season, but rather implies a significant reduction of expenditures on labor and distribution of supplements. 


\section{References}

ARTIOLI, L. F. A.; MORIEL, P.; POORE, M. H.; MARQUES, R. S.; COOKE, R. F. Decreasing the frequency of energy supplementation from daily to three times weekly impairs growth and humoral immune response of preconditioning beef steers. Journal of Animal Science, Champaing, v. 94, n. 1, p. 5430-5441, 2015.

ASSOCIATION OF OFFICIAL ANALYTICAL CHEMISTS - AOAC. Official methods of analysis. $15^{\text {th }}$ ed. Gaithersburg, MD: AOAC, 1990.

ATKINSON, R. L.; TOONE, C. D.; ROBINSON, T. J. Effects of ruminal protein degradability and frequency of supplementation on nitrogen retention, apparent digestibility, and nutrient flux across visceral tissues in lambs fed low-quality forage. Journal of Animal Science, Champaing, v. 88, n. 2, p. 727-736, 2010.

BENATTI, J. M. B.; MORAES, E. H. B. K.; ZERVOUDAKIS, J. T.; ARAÚJO; C. V.; CABRAL, L. S.; RUFINO JUNIOR, J.; CARVALHO, D. M. G. Fornecimento de grão de milheto, inteiro ou triturado, em duas frequências de suplementação para bovinos de corte Revista Brasileira de Zootecnia, Viçosa, v. 41, n. 4, p. 941-950, 2012.

BENATTI, J. M. B.; MORAES, E. H. B. K.; ZERVOUDAKIS, J. T.; ARAÚJO, C. V.; CABRAL, L. S.; RUFINO JUNIOR, J.; CARVALHO, D. M. G.; OLIVEIRA, A. A. Whole or ground millet grain provided in two supplementation frequencies for grazing beef cattle: nutritional parameters. Revista Brasileira de Zootecnia, Viçosa, v. 43, n. 5, p. 250-258, 2014.

BERCHIELLI, T. T.; CANESIN, R. C.; ANDRADE, P. Estratégias de suplementação para ruminantes em pastagens. Revista Brasileira de Zootecnia, Viçosa, v. 35, p. 353-370, 2006. Suplemento 1.

BOHNERT, D. W.; SCHAUER, C. S.; BAUER, M. L.; DEL CURTO, T. Influence of rumen protein degradability and supplementation frequency on steers consuming low-quality low-quality forage: I-Site of digestion and microbial efficiency. Journal of Animal Science, Champaing, v. 80, n. 6, p. 2967-2977, 2002.

CANESIN, R. C.; BERCHIELLI, T. T.; VEGA, A.; REIS, R. A.; MESSANA, J. D.; BALDI, F.; PÁSCOAL, A. G. Reducing supplementation frequency for Nellore beef steers grazing tropical pastures. Scientia Agricola, Piracicaba, v. 71, n. 2, p. 105-113, 2014.

CANESIN, R. C.; BERCHIELLI, T. T.; ANDRADE, R. Desempenho de bovinos de corte mantidos em pastagem de capim-marandu submetidos a diferentes estratégias de suplementação no período das águas e da seca. Revista Brasileira de Zootecnia, Viçosa, v. 36, n. 2, p. 411-420, 2007.
CARTER, R. R.; GROVUM, W. L. A review of the physiological significance of hypertonic body fluids on feed intake and ruminal function: salivation, motility and microbes. Journal of Animal Science, Champaing, v. 68, n. 9, p. 2811-2832, 1990.

COOKE, R. F.; ARTHINGTON, J. D.; ARAUJO, D. B.; LAMB, G. C.; EALY, A. D. Effects of supplementation frequency on performance, reproductive, and metabolic responses of Brahman-crossbred females. Journal of Animal Science, Champaing, v. 86, n. 9, p. 2296-2309, 2008.

DETMANN, E.; VALENTE, E. E. L.; BATISTA, E. D.; HUHTANEN, P. An evaluation of the performance and efficiency of nitrogen utilization in cattle fed tropical grass pastures with supplementation. Livestock Science, New York, v. 162, n. 4, p. 141-153, 2014.

HARVEY, R. W.; CROMM JUNIOR, W. J.; POND, K. R.; HOGARTH, B. W.; LEONARD, E. S. High levels of sodium chloride in supplements for growing cattle. Canadian Journal of Animal Science, Otawa, v. 66, n. 2, p.423-429, 1986.

HUGHES, G. P.; REID, D.; Studies on the behavior of cattle and sheep in relation to utilization of grass. Journal of Agricultural Science, Cambridge, v. 41, n. 4, p. 350355,1951

JOHNSON, A. D. Sample preparation and chemical analisys of vegetation. In: MANEJTE, L. T. (Ed.). Measurement of grassland vegetation and animal production. Aberustwysth: Commonweath Agricultural Bureax, 1978. p. 96-102.

KUNKLE, W. E.; JOHNS, J. T.; POORE, M. H.; HERD, D. B. Designing supplementation programs for beef cattle fed forage-based diets. Proceedings of the American Society of Animal Science, v. 77, n. E, p. 1-11, 2000. Supplement.

LEDGARD, S. F.; WELTEN, B.; BETTERIDGE, K. Salt as a mitigation option for decreasing nitrogen leaching losses from grazed pastures. Journal of the Science of Food and Agriculture, London, v. 96, n. 15, p. 30333040, 2015.

LENG, R. A. Factors affecting the utilization of "poorquality" forages by ruminants particularly under tropical conditions. Nutrition Research Reviews, Cambridge, v. 3, n. 1, p. 277-303, 1990.

LOY, T. W.; KLOPFENSTEIN, T. J.; ERICKSON, G. E.; MACKEN, C. N.; McDONALD, J. C. Effect of supplemental energy source and frequency on growing calf performance. Journal of Animal Sciemce, Champaing, v. 86, n. 12, p. 3504-3510, 2008. 
MERTENS, D. R. Gravimetric determination of amylase treated neutral detergent fiber in feeds with refluxing in beaker or crucibles: collaborative study. Journal of AOAC International, Rockville, v. 85, n. 6 p. 1217-1240, 2002.

MEZZALIRA, J. C.; CARVALHO, P. C. F.; FONSECA, L.; BREMM, C.; REFFATTI, M. V.; POLI, C. H. E. C.; TRINDADE, J. K. Aspectos metodológicos do comportamento ingestivo de bovinos em pastejo. Revista Brasileira de Zootecnia, Viçosa, v. 40, n. 5, p. 1114-1120, 2011.

MIORIN, R. L.; SAAD, R. M.; SILVA, L. D. F.; GALBEIRO, S.; CECATO, U.; MASSARO JUNIOR, F. L. The effects of energy and protein supplementation strategy and frequency on the performance of beef cattle that grazed on Tanzania grass pastures during the rainy season. Tropical Animal Health and Production, Netherlands, v. 48, n. 8, p. 1-7, 2016.

MORAES, E. H. B. K.; PAULINO, M. F.; VALADARES FILHO, S. C.; MORAES, K. A. K.; DETMANN, E.; SOUZA, M. G. Avaliação nutricional de estratégias de suplementação para bovinos de corte durante a estação da seca. Revista Brasileira de Zootecnia, Viçosa, v. 39, n. 3, p. 608-616, 2010.

MORAIS, J. A. S.; QUEIROZ, M. F. S.; KELI, A.; VEGA, A.; FIORENTINI, G.; CANESIN, R. C.; REIS, R. A.; BERCHIELLI, T. T. Effect of supplementation frequency on intake, behavior and performance in beef steers grazing Marandu grass. Animal Feed Science and Technology, Missouri, v. 189, n. 3, p. 63-71, 2014.

NATIONAL RESEARCH COUNCIL - NRC. Nutrient requirements of dairy cattle. $7^{\text {th }}$ ed. Washington: National Academy Press, 2000. 450 p.

PAULA, N. F.; ZERVOUDAKIS J. T.; CABRAL L. S.; CARVALHO, D. M. G.; HATAMOTO-ZERVOUDAKIS, L. K.; MORAE, E. H. B. K.; OLIVEIRA, A. A. Frequência de suplementação e fontes de proteína para recria de bovinos em pastejo no período seco: desempenho produtivo e econômico. Revista Brasileira de Zootecnia, Viçosa, v. 39, n. 4, p. 873-882, 2010.

PULIDO, R. G.; MUÑOZ, R.; LEMARIE, P.; WITTWER, F.; ORELLANA, P.; WAGHORN, G. C. Impact of increasing grain feeding frequency on production of dairy cows grazing pasture. Livestock Science, New York, v. 125, n. 2, p. 109-114, 2009.
RUFINO, L. M. A. Desempenho nutricional e características metabólicas em bovinos alimentados com forragens tropicais e suplementados com compostos nitrogenados e energéticos. 2015. Tese (Doutorado em Zootecnia) - Universidade Federal de Viçosa, Viçosa.

SCHAUER, C. S.; BOHNERT, D. W.; GANSKOPP, D. C.; RICHARDS, C. J.; FALCK, S. J. Influence of protein supplementation frequency on cows consuming low-quality forage: performance, grazing behaviour, and variation in supplement intake. Journal of Animal Science, Champaing, v. 83, n. 7, p. 1715-1725, 2005.

SICHONANY, M. J. O. Efeito de frequências de suplementação no comportamento ingestivo, padrão de deslocamento e ingestão de matéria seca por novilhas de corte. 2012. Dissertação (Mestrado em Zootecnia) Universidade Federal de Santa Maria, Santa Maria.

SIGNORETTI, R. D.; SOUZA, F. H. M.; SCHMIDEK, A.; OLIVEIRA, E. M.; PESSIM, B. Desempenho e comportamento ingestivo de novilhas leiteiras em pastejo submetidas à frequência e níveis de suplementação. Boletim da Indústria Animal, Nova Odessa, v. 69, n. 2, p. 147-154, 2012.

SIMIONI, F. L.; ANDRADE, I. F.; LADEIRA, M. M.; GONÇALVES, T. M.; MATA JÚNIOR, J. I.; CAMPOS, F. R. Níveis e frequência de suplementação de novilhos de corte a pasto na estação seca Revista Brasileira de Zootecnia, Viçosa, v. 38, n. 10, p. 2045-2052, 2009.

SPEK, J. W.; BANNINK, A.; GORT, G.; HENDRIKS, W. H.; DIJKSTRA, J. Effect of sodium chloride intake on urine volume, urinary urea excretion, and milk urea concentration in lactating dairy cattle. Journal of Dairy Science, Champaing, v. 95, n. 12, p. 7288-7298, 2012.

STATISTICAL ANALYSIS SYSTEM - SAS. Statistical analysis system user's guide. Version 8.2 Cary: SAS Institute, 2001. $943 \mathrm{p}$.

VAN SOEST, P. J. Nutritional ecology of the ruminant. $2^{\text {th }}$ ed. Ithaca: Cornell University Press, 1994. 476 p.

ZERVOUDAKIS, J. T.; PAULINO, M. F.; CABRAL, L. S.; DETMANN, E.; VALADARES FILHO, S. C.; MORAES, E. H. B. K. Suplementos múltiplos de autocontrole de consumo na recria de novilhos no período das águas. Ciência e Agrotecnologia, Lavras, v. 32, n. 6, p. 1968-1973, 2008. 